\title{
Adli Tıp Polikliniğinde Adli Rapor Düzenlenen Çocuk Hastaların Değerlendirilmesi
}

\section{The Evaluation of Pediatric Patients with Forensic Reports in a Forensic Medicine Out Patient Clinic}

\author{
Burcu ERSOY, Yasemin BALCI, Yeşim GÖK, Ümit ÜNÜVAR GÖÇEOĞLU
}

Muğla Sıtkı Koçman Üniversitesi Tıp Fakültesi, Adli Tıp Anabilim Dalı, Muğla

\begin{abstract}
Öz
$\mathrm{Bu}$ çalıșmada bir üniversite hastanesi adli tıp polikliniğine adli nitelikle başvuran çocuk olguların sosyodemografik özelliklerini ortaya koymak, yaş gruplarına göre adli tıbbi değerlendirmelerde dikkat edilecek hususları belirlemek ve koruyucu hekimlik adına öneriler geliştirmek amaçlanmıştır. 01.06.2014-31.12.2018 tarihleri arasında düzenlenen, 18 yaş altındaki olgulara ait raporlar retrospektif olarak taranmıştır. Olgular yaş, cinsiyet, hangi tür olay nedeniyle rapor talep edildiği, rapor talep eden birimler, olay tarihi, daha önce aynı konuda rapor düzenlenip düzenlenmediği, travma olgularında yaralanma ağırlığı ve rapor sonuçları açısından değerlendirilmiştir. Toplam 7556 rapordan 1107'si (\%14.6) 18 yaşından küçük çocuk olgular için düzenlenmiştir. Olguların 657'si (\%59.3) erkek, 450'si (\%40.7) kadındır. Olguların \%41.8'i 12 yaşın altındadır. Başvuruların büyük bölümü (\%63.4) il merkezinden yapılmıştır. Rapor talebi en fazla adli kolluk birimlerince (\%85.1) yapılmıştır. Olgular en sık Kasım ayında ve sonbahar mevsiminde, en çok travmatik olaylar nedeniyle başvurmuştur. Travma, cinsel istismarlar ve adli psikiyatrik olgular 12 yaş ve üstünde, intoksikasyonlar 11 yaș ve altında anlamlı ölçüde yüksek bulunmuştur. Çocukların sağlıklı bir şekilde yetişmesi için tüm olumsuz faktörlerin belirlenmesi ve önleme çalışmalarının yapılması adına adli muayeneler de çocukları koruma girişimleri açısından önemli firsatlar olabilir. Çocukların sağlıklı yetișebilmesi, adli olaylar, travma ve şiddet olaylarına karışmalarının en aza indirilebilmesinde aile, eğitim kurumları ve hükümetlere önemli görevler düşmektedir.
\end{abstract}

Anahtar Kelimeler: Adli Rapor, Adli Tıp, Çocuk

\section{Giriş}

Ulusal ve uluslararası mevzuata göre 18 yaşını tamamlamamış tüm bireyler çocuktur. Çocuklar, karşı karşıya kaldıkları tehlikeler sonucu maruz kaldıkları fiziksel, cinsel ve ruhsal travmalar ya da suça sürüklenme durumlarında adli olgu olarak karşımıza çıkmaktadır. Adli tıp olguları içinde çocuk olgular kayda değer bir yer tutmakta olup kendi içinde özellikleri bulunmaktadır. Daha önce farklı illerde yapılan çalışmalarda da çocuk adli olgular değerlendirilmiştir.

Çocuk adli olguların başvuru nedenleri bölgesel ve başvurduğu hastaneye göre farklıliklar gösterebilmektedir (1-5). Bu çalışmada, Muğla

\begin{tabular}{ll}
\hline & ORCID No \\
Burcu ERSOY & $0000-0002-4933-8470$ \\
Yasemin BALCI & $0000-0002-5995-9924$ \\
Yeşim GÖK & $0000-0002-4829-4293$ \\
Ümit ÜNÜVAR GÖÇEOĞLU & $0000-0003-1646-7492$ \\
& \\
Başvuru Tarihi / Received: & 07.11 .2019 \\
Kabul Tarihi / Accepted : & 21.08 .2020 \\
Adres / Correspondence : & Burcu ERSOY \\
Muğla Sitk1 Koçman Üniversitesi Tip Fakültesi, Adli Tip Anabilim Dalı, \\
$\begin{array}{l}\text { Muğla } \\
\text { e-posta / e-mail }\end{array}$ \\
\hline
\end{tabular}

\begin{abstract}
In this study, it was aimed to reveal the sociodemographic characteristics of pediatric cases admitted to a forensic medicine outpatient clinic of a university hospital, to determine the issues to be considered in forensic medical evaluations according to age groups and to make recommendations for preventive medicine. The reports of the patients under the age of 18 , which were organized between 01.06.2014-31.12.2018, were reviewed retrospectively. The cases were evaluated in terms of age, sex, type of incident, requesting units, event date, history of forensic report subject, severity of injury and results of reports. Of the total 7556 reports, $1107(14.6 \%)$ were prepared for those under the age of $18.657(59.3 \%)$ were male, $450(40.7 \%)$ were female. $41.8 \%$ of the cases were under the age of 12 . The majority of the applications $(63.4 \%)$ applied from the city center. The most frequently requested by police units $(85.1 \%)$. Most of the cases were presented in November and in the autumn season. The applications were mostly due to traumatic events. 12 years and over were significantly higher in trauma, sexual abuse and forensic psychiatric cases, whereas 11 years and under were significantly higher in intoxications. For the purpose of identifying all negative factors and conducting prevention studies, forensic examinations can also be important opportunities for child protection initiatives. Families, educational institutions and governments have important duties in keeping children healthy and minimizing their involvement in forensic events, trauma and violence.
\end{abstract}

Keywords: Forensic Report, Forensic Medicine, Child

Sitk1 Koçman Üniversitesi, Eğitim-Araştırma Hastanesi Adli Tıp Polikliniğine yansıyan çocuk adli olguların değerlendirilmesi ile adli nitelikli başvuran çocuk olguların bölgesel özelliklerini ortaya koyabilmek, olgu gruplarına göre adli tıbbi değerlendirmelerde dikkat edilecek hususların belirlenmesi ve koruyucu hekimlik adına öneriler geliştirebilmek amaçlanmıştır.

\section{Gereç ve Yöntem}

Çalışmada, 01.06.2014-31.12.2018 tarihleri arasında Muğla Sıtkı Koçman Üniversitesi Eğitim ve Araştırma Hastanesi Adli Tıp Polikliniğinde düzenlenen, 18 yaş altındaki olgulara ait raporlar retrospektif olarak incelenmiştir. Olgular yaş, cinsiyet, hangi tür olay nedeniyle rapor talep edildiği, rapor talep eden birimler, olay tarihi, daha önce aynı konuda rapor düzenlenip düzenlenmediği, travma olgularında yaralanma ağırlığı ve rapor sonuçları açısından değerlendirilmiştir.

Olguların yaşları, okula başlama yaşı, işlediği fiilin hukuki anlam ve sonuçlarını algılayıp algılamadığı veya davranışlarını yönlendirme 
yeteneğinin yeterince gelişmiş olup olmadığ1 konusunda değerlendirilmesinin gerektiği ya da gerekmediği yaș aralıklarına göre, 0-6, 7-11, 12-14 ve 15-17 olarak gruplandırılmıştır.

Olay türleri; travmalar, cinsel istismar, intoksikasyonlar, adli psikiyatrik olgular ve diğer olmak üzere beş gruba ayrılmıştır. Çalışma grupları;

1-Travma grubu; etkili eylem, trafik kazası, eş/partner şiddeti, iş kazası, düşme, ateşli silah yaralanması, diğer kazalar, kesici-delici alet yaralanması, hayvan saldırısı, elektrik çarpması olgularını kapsamıştır.

2-İntoksikasyonlar grubu; intihar girişimleri, karbonmonoksit zehirlenmeleri ve diğer intoksikasyon nedenli başvuran olguları kapsamıştır.

3-Cinsel istismar grubu; bir cinsel istismar/saldırı olayının mağduru olan çocuk olguları kapsamaktadır.

4-Adli psikiyatri olguları grubu; evlilik iptali, akıl sağlığının belirlenmesi, fiilin hukuku anlam ve sonuçlarını kavrama ve davranışlarını yönlendirme yeteneği gibi adli psikiyatrik değerlendirme talep edilen olguları kapsamaktadır.

5-Diğer grubu; alkol tetkiki, malpraktis, yaș tahmini, uyuşturucu- uyarıcı madde tetkiki gibi olgular diğer grubunda değerlendirilmiştir.

Elde edilen veriler SPSS 22 paket istatistik programı kullanılarak analiz edilmiş; frekans ve yüzde analizleri yanı sıra cinsiyete göre, yaş gruplarına ve mevsimlere göre olay türlerinin dağılımı karşılaştırmalı tablolar halinde verilmiştir.

$\mathrm{Bu}$ çalışma için, Muğla Sıtkı Koçman Üniversitesi Bilimsel Araştırmalar ve Yayın Etiği Kurulu'nun 26.07.2019 tarih ve 119 karar numaralı onayı alınmıştır.

\section{Bulgular}

01.06.2014-31.12.2018 tarihleri arasında Adli Tıp Polikliniğinde toplam 7556 rapor düzenlenmiş olup bunların 1107'si (\%14.6) 18 yaşından küçük çocuk olgulardır. Çocuk olguların 657'si (\%59.3) erkek, 450’si (\%40.7) kadındır.

Adli tıp polikliniğine yansıyan çocuk olgular içinde en büyük grubu 17 yaşındaki çocuklar (\%15.6) oluşturmaktadır. Bunu sırasıyla 16, 15 ve
14 yaşındaki çocuklar izlemektedir. Toplam olguların \%58.2'sini 12 yaş ve üzerindeki çocuklar oluşturmaktadır.

Olguların büyük bölümü $\quad(n=702, \% 63.4)$ polikliniğe il merkezinden başvurmuştur. Bunu sırasıyla Köyceğiz $(n=80, \% 7.2)$, Ula $(n=78, \% 7.1)$ ve Yatağan $(n=69, \% 6.2)$ ilçeleri takip etmiştir. Olguların gönderildikleri ilçelere göre dağılımı Tablo 1'de gösterilmiştir.

Tablo 1. Olguların gönderildikleri ilçelere göre dağılımı

\begin{tabular}{lcc}
\hline Geldiği İlçe & n & \% \\
\hline Merkez & 702 & 63.4 \\
Köyceğiz & 80 & 7.2 \\
Ula & 78 & 7.1 \\
Yatağan & 69 & 6.2 \\
Bodrum & 42 & 3.8 \\
Ortaca & 30 & 2.7 \\
Milas & 29 & 2.6 \\
Kavaklıdere & 19 & 1.7 \\
Marmaris & 14 & 1.3 \\
Dalaman & 14 & 1.3 \\
Datça & 11 & 1.0 \\
Fethiye & 11 & 1.0 \\
Seydikemer & 2 & .2 \\
Diğer & 6 & .5 \\
Toplam & 1107 & 100.0 \\
\hline
\end{tabular}

Olguların rapor talebinde bulunan birimlere göre dağılımı Tablo 2'de sunulmuştur. Olguların $\% 85.1$ 'inde $(\mathrm{n}=943)$ adli kolluk birimlerince rapor talebi olmuştur.

Olguların \%82.5'inde daha önceden en az bir adli rapor düzenlenmiş olduğu tespit edilmiştir. Direkt adli tıp polikliniğinde rapor düzenlenme oran1 $\% 17.5$ 'dir.

Tablo 2. Rapor talep eden makamların dağılımı

\begin{tabular}{lcc}
\hline Makam & n & \% \\
\hline Polis & 687 & 62.0 \\
Jandarma & 256 & 23.1 \\
Yarg1 & 126 & 11.4 \\
Cezaevi & 18 & 1.6 \\
Diğer* & 20 & 1.8 \\
Toplam & 1107 & 100.0 \\
\hline
\end{tabular}

*:Diğer iller ya da Kurumlardan

Polikliniğe müracaat ettirilen çocuk olguların büyük bölümüne $(\% 72.2)$ hastanede yatmay1 gerektirmeyecek nedenlerle rapor düzenlenmiştir.

Cinsiyete göre rapora konu olan olay türlerinin dağılımı Tablo 3'de verilmiştir.

Tablo 3. Olguların cinsiyetine göre olay türlerinin dağılımı

\begin{tabular}{|c|c|c|c|c|c|c|c|c|c|c|c|c|}
\hline & \multicolumn{2}{|c|}{ Travma } & \multicolumn{2}{|c|}{ İntoksikasyon } & \multicolumn{2}{|c|}{ Cinsel İstismar } & \multicolumn{2}{|c|}{ Adli Psikiyatri } & \multicolumn{2}{|c|}{ Diğger } & \multicolumn{2}{|c|}{ Toplam } \\
\hline & $\mathbf{n}$ & $\%$ & $\mathbf{n}$ & $\%$ & $\mathbf{n}$ & $\%$ & $\mathbf{n}$ & $\%$ & $\mathbf{n}$ & $\%$ & $\mathbf{n}$ & $\%$ \\
\hline Erkek & 443 & 67.4 & 121 & 18.4 & 25 & 3.8 & 55 & 8.4 & 13 & 2.0 & 657 & 100.0 \\
\hline Kadın & 225 & 50.0 & 112 & 24.9 & 68 & 15.1 & 24 & 5.3 & 21 & 4.7 & 450 & 100.0 \\
\hline Toplam & 668 & 60.4 & 233 & 21.0 & 93 & 8.4 & 79 & 7.1 & 34 & 3.1 & 1107 & 100.0 \\
\hline
\end{tabular}


Adli tıp polikliniğine başvuran çocuk olgular içinde en büyük grubu $(n=668, \% 60.4)$ travma olguları oluşturmaktadır. $\mathrm{Bu}$ olgular, vücut dokunulmazlığına karşı suçlar kapsamında, travma ağırlığının belirlenmesi açısından, rapor düzenlenmesi amaciyla polikliniğimize yönlendirilmiş olgulardır. Bunu \%21.0 oranıyla intoksikasyonlar izlemektedir.

Cinsiyete göre olay türleri değerlendirildiğinde, travma ve adli psikiyatrik açıdan değerlendirilen olgular içinde erkekler kadınlara göre istatistiksel olarak anlamlı ölçüde daha fazla iken cinsel istismar olguları içinde ise kadın olgular erkeklere göre istatistiksel olarak anlamlı ölçüde daha fazladır (Kikare:69.13, df:4, $\mathrm{p}=0.000$ ).

Olguların yaş gruplarına göre olay türlerinin dağılımı Tablo 4'de gösterilmiştir. En büyük grubu 15-17 yaş aralığındaki olgular (\%36.6) oluşturmaktadır. Yaş gruplarına göre olay türleri değerlendirildiğinde; intoksikasyon olgularının 0-6 grubunda diğer yaş gruplarına göre oldukça fazla olduğu (\%57.1), cinsel istismar olgularının ise 7 yaş ve üzerindeki gruplarda daha fazla olduğu (\%90.3), adli psikiyatrik olguların ise 12-14 yaş grubunda yoğunlaştığı $\quad(\% 77.2) \quad$ görülmektedir.

Tablo 4. Olguların yaş gruplarına göre olay türlerinin dağılımı (n)

\begin{tabular}{lcccccc}
\hline Yaş grubu & Travmalar & İntoksikasyonlar & $\begin{array}{c}\text { Cinsel } \\
\text { İstismarlar }\end{array}$ & $\begin{array}{c}\text { Adli } \\
\text { Psikiyatrik }\end{array}$ & $\begin{array}{c}\text { Diğer } \\
\text { Toplam }(\%)\end{array}$ \\
\hline $0-6$ & 135 & 133 & 9 & 1 & 4 & $282(25.5)$ \\
$7-11$ & 135 & 23 & 18 & 4 & 1 & $181(16.4)$ \\
$12-14$ & 121 & 21 & 28 & 61 & $238(21.5)$ \\
$15-17$ & 277 & 56 & 38 & 13 & 22 & $406(36.6)$ \\
Toplam & 668 & 233 & 93 & 79 & 34 & $1107(100.0)$ \\
\hline
\end{tabular}

Mevsimlere göre olay türlerinin dağılımı ise Tablo 5'te gösterilmiştir.

Tablo 5: Olguların ay ve mevsimlere göre dağılımı

\begin{tabular}{lccccc}
\hline Aylar & n & \% & Mevsimler & n & \% \\
\hline Aralık & 96 & 8.7 & Kış & 238 & 21.5 \\
Ocak & 69 & 6.2 & & & \\
Şubat & 73 & 6.6 & & & \\
Mart & 102 & 9.2 & İlkbahar & 269 & 24.3 \\
Nisan & 64 & 5.8 & & & \\
Mayıs & 103 & 9.3 & & & \\
Haziran & 91 & 8.2 & Yaz & 273 & 24.7 \\
Temmuz & 98 & 8.9 & & & \\
Ăgustos & 84 & 7.6 & & & \\
Eylül & 89 & 8.0 & Sonbahar & 327 & 29.5 \\
Ekim & 95 & 8.6 & & & \\
Kasım & 143 & 12.9 & & & \\
Toplam & 1107 & 100.0 & Toplam & 1107 & 100.0 \\
\hline
\end{tabular}

Çocuk olgularda rapor düzenlenmesini gerektiren olaylar en çok Kasım ayında (\% 12.9) en az ise Nisan ayında (\%5.8), mevsimsel olarak en fazla sonbahar (\%29.5), en az kış (\%21.5) mevsiminde olmuştur. Travma ve cinsel istismar olgularının en sik sonbahar aylarında, intoksikasyonların en çok kış aylarında, adli psikiyatrik açıdan değerlendirilen olguların ise en sık ilkbahar ve yaz aylarında görüldüğü saptanmıştır.

Travmalar: Travma ağırlığının belirlenmesi amaciyla rapor düzenlenen olgularda, travma türlerinin dağılımı Tablo 6'da gösterilmiştir.

Travma nedeniyle yapılan başvurular içinde en fazla trafik kazası (\%47.3) yer alırken ikinci sırayı etkili eylem (\%32.8) almıştır. Trafik kazası olgularının 203'ü erkek (\%64.2), 113'ü kadın (\%35.8), etkili eylem olgularının 159'i erkek (\%72.6), 60’1 kadındır (\%27.4).

Travma olgularında yaralanma ağırlığı ile ilgili hususların dağılımı Tablo 7'de verilmiştir.
Tablo 6. Travmalı olgularda, travma türlerinin dağılımı

\begin{tabular}{lcc}
\hline Travma Türü & $\mathbf{n}$ & $\mathbf{\%}$ \\
\hline Trafik kazası & 316 & 47.3 \\
Etkili Eylem & 219 & 32.8 \\
Diğer kaza & 39 & 5.8 \\
Düşme & 33 & 4.9 \\
Aile içi şiddet (2'si eş) & 30 & 4.5 \\
Ateşli silah yaralanması & 9 & 1.4 \\
İs kazası & 8 & 1.2 \\
Hayvan saldırısı & 6 & 0.9 \\
Kesici-delici alet yaralanması & 4 & 0.6 \\
Elektrik çarpması & 4 & 0.6 \\
Toplam & 668 & 100.0 \\
\hline
\end{tabular}

Travma olgularının 440'ında (\%65.9) meydana gelen yaralanmanın basit bir tıbbi müdahale ile giderilebilecek ölçüde hafif nitelikte olduğu, 60'ında (\%9) yaşamsal tehlikeye neden olduğu saptanmıştır. Yüzde sabit iz açısından; olguların 617'sinin yüzde sabit iz niteliğinde olmadığı, 49 olgu için meydana gelen yaralanmanın yüzde sabit iz niteliği taşıyıp taşımadığının belirlenmesi açısından 6 ay sonra tekrar muayene edilmesi gerektiği, sadece 2 olguda $(\% 0.3)$ yaralanmanın yüzde sabit iz niteliğinde olduğu yönünde rapor düzenlenmiştir. 67 olguda, duyu veya organlarından birinin işlevinin sürekli zayıflaması ya da yitirilmesi açısından 18 ay sonra yeniden değerlendirilmesinin uygun olacağı, 3 olguda $(\% 0.5)$ işlevde sürekli zayıflık/işlev yitimi meydana geldiği şeklinde rapor düzenlenmiştir. Travma olgularının 160'ında (\%24.0) vücutta kemik kırığ meydana geldiği, bunların 27 'sinde meydana gelen kemik kırıklarının hayat fonksiyonlarına etkisinin hafif olduğu, 76'sında orta, 57'sinde ağır olduğu belirlenmiştir. 
Tablo 7. Travma olgularında yaralanma ağırlığının dağılımı

\begin{tabular}{lcl} 
BTM* ile giderilebilecek nitelikte; & n & \% \\
\hline Hafif olduğu & 440 & 65.9 \\
Hafif olmadığı & 228 & 34.1 \\
Yaşamsal Tehlike & & \\
Yok & 608 & 91.0 \\
Var & 60 & 9.0 \\
Yüzde sabit iz & & \\
Yok & 617 & 92.4 \\
6 ay sonra değerlendirilmeli & 49 & 7.3 \\
Var & 2 & 0.3 \\
Kalıcı işlev zayıflığı/yitimi & & \\
Yok & 598 & 89.5 \\
18 ay sonra değerlendirilmeli & 67 & 10.0 \\
Var & 3 & 0.5 \\
Kemik Kırığı & & \\
Yok & 508 & 76.0 \\
Hafif (1 puanlı) & 27 & 3.1 \\
Orta (2-3 puan) & 76 & 11.4 \\
A ğır (4-5-6 puan) & 57 & 8.5 \\
\end{tabular}

İntoksikasyonlar: Çocuk yaş grubundaki intoksikasyon olgularında zehirlenme etkenlerin dağılımı Tablo 8'de verilmiștir.

Çocuk yaş grubu intoksikasyon olgularında zehirlenme etkeni açısından sıklık sırasına göre ilk 3 sırayı ilaç ve madde kullanımı, koroziv maddelere maruz kalma ve gida intoksikasyonları almaktadır. Bunu karbonmonoksit zehirlenmeleri takip etmektedir. T1bbi belge ve raporlarda etkeni kayitlı olmayan zehirlenme olgularının da çoğunluğunun ilaç olduğu tahmin edilmektedir. Bilinmeyen olgular çıkarıldığında ilaç alma oranı \%39.5'tir. İntoksikasyon olgularının sadece 9'unda (\%3.9) yaşamsal tehlike oluştuğu, 6'sında (\%2.6) oluşan sağlık zararının basit tıbbi müdahale ile giderilebilecek derecede hafif olmadığı, geri kalanlarında ise $(\% 97.5)$ basit tıbbi müdahale ile giderilebilecek derecede hafif nitelikte olduğu belirlenmiştir. Yaşamsal tehlike oluşan 9 olgunun tamamı karbonmonoksit zehirlenmesidir. Basit tıbbi müdahale ile giderilebilecek derecede hafif olmayan intoksikasyon olgularının da 3'ü ilaç alımı, 2'si karbonmonoksit maruziyeti, 1'i de koroziv madde alımıdır.

Çocuk intihar girişimleri: Adli rapor düzenlenen çocuk olguların 32'sinde (\%2.9) intihar girişimi öyküsü vardır. Bunların 25'i ilaç/madde alımı olup intoksikasyonlar içinde değerlendirilmiştir. Geri kalan 7 olguda kesici/kesici-delici alet kullanımı söz konusudur. Kesici/kesici-delici alet kullanan olguların birinde yaşamsal tehlike oluşmuş, birinde de yaralanma basit tıbbi müdahale ile giderilebilecek derecede hafif olmayıp diğerleri hafif yaralanma olarak değerlendirilmiştir.

Cinsel istismar olgular1: Toplam 93 cinsel istismar olgusunun 25'i erkek (\%26.9), 68' $\mathrm{i}$ kadındır (\%73.1). 34'ü olaydan sonra 10 gün içinde görülen akut sayılabilecek olgulardır. 20 olguda, iç beden muayenesinde cinsel istismarı düşündüren bulgu saptanmıştır. Buna karşılık 61 olguda, muayene ve adli görüşme sonucu ulaşılan bulgular ya da soruşturma evraklarının incelenmesiyle ulaşılan bilgiler neticesinde, cinsel istismar düşünüldüğü belirtilmiştir. 12 olguda olayın adli tahkikatla aydınlatılması uygun bulunmuştur. Cinsel istismar iddiasıyla muayene edilen olguların yaşları 1-17 arasında değişmekte olup 9 olgu 7 yaşından küçüktür.

Tablo 8. Çocuk yaş grubundaki intoksikasyon olgularında zehirlenme etkenlerin dağılımı

\begin{tabular}{lcc}
\hline Zehirlenme Etkeni & n & \% \\
\hline İlaç /madde* & 77 & 33.0 \\
Koroziv maddeler & 37 & 15.9 \\
Gıda & 31 & 13.3 \\
Karbonmonoksit & 21 & 9.0 \\
Zirai ilaçlar & 7 & 3.1 \\
Diğer etkenler & 22 & 9.4 \\
Bilinmeyen & 38 & 16.3 \\
Toplam & 233 & 100.0 \\
\hline
\end{tabular}

Adli psikiyatrik olgular: Adli psikiyatrik değerlendirmesi yapılan toplam 79 olgunun 66's1 (\%83.5), Türk Ceza Kanunu 31. madde kapsamında 'küçüğün, işlediği fiilin hukuki anlam ve sonuçlarını algılayıp algılamadığı veya davranışlarını yönlendirme yeteneğinin yeterince gelişip gelişmediği', 5 kadın olgu için ruhen ve bedenen evliliğe hazır olup olmadiğı, 4 olgunun ceza sorumluluğunun olup olmadığı, 3 olgunun beden ve ruh bakımından kendini savunup savunamayacağı, 1 olgunun ifadelerine itibar edilip edilemeyeceği hususunda rapor düzenlenmiş olup, tüm olgulardan ruh sağlığı ve hastalıkları uzmanlarından konsültasyon alındığı görülmüştür.

Diğer olgular: Diğer olgular içinde en fazla yaş tayini istenen olgular mevcuttur. Diğer grubundaki 34 olgunun 20'si (\%58.8) yaş tayini istenen olgulardır. Olguların 7'sinde alkol tetkiki, 2'sinde hekim hatası olup olmadığının aydınlatılması istemiş geri kalan olgularda da DNA incelemesi yapılıp yapılamayacağı, küçüğün kimin yanında kalmasının uygun olacağı gibi seyrek karşılaşılan sorular sorulmuştur.

\section{Tartışma}

Çocuklar, trafik kazaları, zehirlenme, düşme, her türlü istismar ve ihmal, etkili eylem, ateşli silah yaralanmaları ve delici-kesici alet yaralanmaları gibi biyo-psiko-sosyal açıdan sağlıklarını etkileyen birçok adli olayla karşılaşabilmektedir. Bu olayların bir kısmı çeşitli nedenlerle herhangi bir sağlık kuruluşuna yansımamakta, yansıyanların ise bir kısmı adli olgu olarak değerlendirilmemektedir. Bu çalışmada, 4,5 yıllık süreçte adli olgu olarak değerlendirilip adli rapor düzenlenmesi amacıyla Adli Tıp Polikliniğine yönlendirilen olgular değerlendirilmiştir. Adli Tıp Polikliniğinde rapor düzenlenen olguların \%14.6'sı çocuktur. Çocuk adli olgu oranının verildiği çalışmalarda, tüm adli olgular içinde çocuk oranının \%18 ile \%36.6 
arasında olduğu bildirilmiştir (1-3,6). Çalışmamızdaki çocuk olgu oranının diğer çalışmalara göre nispeten düşük olmasının nedeni ilin sosyokültürel özellikleri olabileceği gibi bir neden de diğer çalışmaların acil servislere yansıyan çocuk olguları kapsaması olabilir.

Olguların büyük bölümü (\%63.4) polikliniğe il merkezinden başvurmuştur. Bunu sirasiyla Köyceğiz (\%7.2), Ula (\%7.1) ve Yatağan \%6.2) ilçeleri gibi il merkezine daha yakın olan ilçeler takip etmiştir (Tablo 1). Yapılan benzer çalışmalarda da il merkezinden yapılan başvuruların çoğunlukta olduğu belirtilmiştir $(7,8)$.

Olguların \%85'inde adli kolluk birimlerince rapor talebinde bulunulmuştur (Tablo 2). Yarg1 organlarından gelen talebin daha düşük olmasının nedeni; yargı birimlerinin raporları genellikle polis veya jandarma aracılığıyla aldırmaları ve adli tıp polikliniklerinin UYAP sistemine dâhil olmamasına bağlanmıştır. Erzurum'da yapılan bir çalışmada; Adli Tıp Şube Müdürlüğüne gelen adli rapor taleplerinin \%91.6'sinın Cumhuriyet Başsavcılıklarından yapıldığı bildirilmiştir (9). Keza Adli Tıp Şube Müdürlüklerinden raporlar UYAP üzerinden talep edilmektedir.

Adli rapor düzenlenen çocuk olgularda erkek sayısının fazlalığına işaret eden çalışmalar $(3-5,10)$ olduğu gibi kadın-erkek oranının birbirine yakın olduğu (1,2) çalışmalar da mevcuttur. Çalışmamızda, Adli Tıp Polikliniğinde rapor düzenlenen çocuk olguların \%59.3'ünün erkek olduğu görülmektedir.

Olguların \% 82.5'inde daha önceden en az bir adli rapor düzenlenmiş olduğu saptanmıştır. Genellikle ilk başvuru yapılan yerlerde geçici rapor verilmesi bu duruma yol açmaktadır. Poliklinikte rapor düzenlenen çocuk olguların \%72'sinin hastanede yatışının olmadığı saptanmıştır. Çoğunluğu basit bir tıbbi müdahale ile giderilebilir ölçüde hafif nitelikte ve yaşamsal tehlikeye yol açmayan yaralanmalar olduğu göz önüne alındığında, bu olgulara ilk başvuru yeri olan sağlık birimlerinde geçici rapor verilmesi yarg1 sürecini gereksiz yere uzatmaktadır. Basit nitelikli adli olgularda ilk başvuru yeri olan acil servislerde yargıyı tatmin edecek raporların verilebilmesi için gerekli eğitim ve düzenlemeler yapılmalıdır.

Adli tıp polikliniğine başvuran çocuk olgular içinde en büyük grubu (\%60.4) travma olguları alırken bunu sirasıyla intoksikasyonlar (\%21), cinsel suç olguları (\%8.4) ve adli psikiyatrik olgular (\%7.1) takip etmektedir. Cinsiyete göre olay türleri değerlendirildiğinde, erkeklerde travma ve adli psikiyatrik değerlendirme gerektiren olgular, kadınlarda ise intoksikasyon ve cinsel istismar olguları diğer cinsiyete göre istatistiksel olarak anlamlı ölçüde daha fazladır $(\mathrm{p}<0.001)$ (Tablo 3). Sonuçlar literatürdeki benzer çalışmalarla uyumludur (10-17).
Adli tıp polikliniğine yansıyan çocuk olgular içinde en büyük grubu 15-17 yaşındaki olgular (\%36.6) oluşturmaktadır. Çocuk olgularda yaş grubunun değerlendirildiği diğer çalışmalarda, bizim çalışmamızdan farklı olarak 0-5 yaş, 0-6 yaş veya 7-10 yaş arasındaki olguların çoğunlukta olduğu bildirilmiştir $(2-4,10)$. Bu farklılığın nedeni diğer çalışmaların çoğunlukla acil servise yansıyan çocuk olguları kapsamasına ve çalışma dizaynı farklılığına bağlanmıştır. Özellikle küçük yaş grubunu ilgilendiren intoksikasyon ve kazalara ait olgularda, yarg1 mensuplarınca acil servis raporlarıla yetinildiği düşünülmüştür. Çalışmamızda, intoksikasyon olgularının 0-6 yaş grubunda diğer yaş gruplarına göre oldukça fazla olduğu (\%57.1), cinsel istismar olgularının ise 7 yaş ve üzerindeki gruplarda daha fazla olduğu (\%90.3), adli psikiyatrik olguların ise 12-14 yaş grubunda yoğunlaştığı (\%77.2) görülmektedir (Tablo 4).

Olgu türüne göre yaş grupları değerlendirildiğinde çalışmamız literatürle uyumlu bulunmuştur $(15,16)$. 0-6 yaş grubu çocukların oluşabilecek tehlikeli durumları algılayamamaları ve özellikle oral dönemde her şeyi ağızlarına götürme eğilimleri, kaza sonucu zehirlenme riskini arttırmaktadır. Ergen grupta ise cinsel istismar olgularındaki fazlalık literatürle uyumlu bulunmuştur (18). Adli psikiyatrik olguların 12-14 yaş grubunda yoğunlaşmasının nedeni, Türk Ceza Kanunu'na göre, bu yaş grubunda, işlediği fiilin hukuki anlam ve sonuçlarını algılayıp algılamadığı veya davranışlarını yönlendirme yeteneğinin yeterince gelişip gelişmediğinin tespitinin gerekli olmasıdır. Aydın'da yapılan bir çalışmada adli tıp ve çocuk ve ergen ruh sağlığı ve hastalıkları polikliniklerine yansıyan olgular değerlendirilmiş, olguların \%75'ini 12-15 yaş grubunun oluşturduğunun bildirilmiştir (5).

Mevsimsel dağılıma bakıldığında; çocuk adli olgulara en çok sonbahar aylarında (\% 29.5), en az kış aylarında (\%21.5) karşılaşıldığı saptanmıştır. Mevsimsel dağılımla ilgili benzer sonuçların bildirildiği çalışmalar olduğu gibi bölgesel farklılıkların bildirildiği çalışmalar da mevcuttur $(6,7,9,19,20)$. Dicle Üniversitesi Adli Tıp Anabilim Dalına ve Erzurum Adli Tıp Şube Müdürlüğü'ne en fazla k1ş mevsiminde adli olgu müracaat ettiği bildirilirken (7,9), adli olayların en sik yaz aylarında meydana geldiğini bildiren çalışmalar da mevcuttur $(3,8,21,22)$. Olayların en az kış mevsiminde görülüyor olması açısından, bulgularımız Diyarbakır ve Erzurum'da yapılan çalışmalar dışında literatürle uyuşmaktadır (2$4,8,19,20)$. Gerek iklimsel gerekse diğer nedenlerle olan nüfus hareketleri adli olgu sayısını etkilemektedir. Travma olguları ve cinsel istismar olguları en sık sonbahar aylarında görülürken, intoksikasyonlar en çok kış aylarında, adli psikiyatrik olgular en sik ilkbahar ve yaz aylarında görülmüştür (Tablo 5). Yaz aylarında, nüfusun bir 
kısmının, şehir merkezinden turizm amaçlı olarak ilçelere yönelmesi ve sonbahar mevsiminde özellikle okulların açılmasıyla birlikte günlük hayatta oluşan hareketliliğin, hem genel olgu sayısında, hem de travma ve cinsel suç olgularının sayısında artışa neden olabileceği düşünülmüştür. İntoksikasyon olgularının kış aylarında daha fazla görülmesinin de, isınma ihtiyacı nedeniyle kış mevsiminin karbonmonoksit zehirlenmelerine aç1k olması, evlerde daha çok zaman geçirilmesi ve mevsimsel olarak ruhsal durumun olumsuz etkilemesi ile ilişkili olabileceği düşünülmüştür.

Travma nedeniyle yapılan başvurular içinde en fazla trafik kazası $(\% 47.3)$ yer alırken ikinci sırayı etkili eylem (\%32.8) almıştır. Trafik kazası olgularının \%64.2'si, etkili eylem olgularının \%72.6's1 erkektir (Tablo 6).

En sık görülen olayın trafik kazası olması benzer çalışmalarla uyumlu bulunurken diğer olguların sıralaması değişkenlik gösterebilmektedir $(6,10,21,22$,$) . Genel olarak tüm travma olguları$ yanı sıra, trafik kazaları ve etkili eylem sonucu başvuran olguların da çoğunluğu literatürle uyumlu şekilde erkek cinsiyetlidir (1,6,10-21,23,24). Sonuçların, ev dışında ve trafikte daha fazla vakit geçirmelerine, ayrıca erkek çocuklara öğretilen toplumsal cinsiyet rolleri, riskli davranışlara daha meyilli olmaları ile ilişkili olabileceği düşünülmüştür.

Travma olguları: Travmalı çocuk olguların \%65.9'unda meydana gelen yaralanmanın basit bir tıbbi müdahale ile giderilebilecek ölçüde hafif nitelikte olduğu belirlenirken, yaşamsal tehlike oranı \%9 bulunmuştur. Travma olgularının \%24'ünde vücutta kemik kırığı meydana geldiği, sadece 2 olguda $(\% 0.3)$ yaralanmanın yüzde sabit iz niteliğinde olduğu, 3 olguda $(\% 0.5)$ işlevde sürekli zayıflık/işlev yitimi meydana geldiği yönünde rapor düzenlenmiştir (Tablo 7). Adli tıbbi sonucun kaydedildiği çalışmalarda yaşamsal tehlike oranı daha yüksek bulunmuştur $(7,8,25,26)$. Bu çalışmalar tüm adli olguları kapsamaktadır. Çalışmamızda yüzde sabit iz ve kalıcı işlev zayıflı̆̆ı/işlev yitimi saptanma oranının düşük olmasının nedeni, polikliniğimizde düzenlenen ilk rapordan sonra sabit iz için 6 ay sonra, işlev kaybı/zayıflı̆̆1 için 18 ay sonra yapılacak değerlendirmelerin çoğunun yarg1 birimlerince UYAP üzerinden Adli Tıp Şube Müdürlüğüne yönlendirilmesi ile açıklanmıştır.

Çocuk yaş grubu intoksikasyonlar: Bu olgularda zehirlenme etkeni açısından sıklık sırasına göre ilk 3 sırayı ilaç ve madde kullanımı, koroziv maddelere maruz kalma ve gıda intoksikasyonlarının alması, bu konuda yapılan çalışmalarla uyumludur $(13,15,21,27)$. Çocukların ev içinde ilaçlara ulaşımının kolaylığının ilaç kaynaklı intoksikasyonlarda rolü olduğu söylenebilir. Sürekli kullanılması gereken ve acil durumlarda kullanılabilecek ilaçlar dışında evde ilaç bulundurulmaması ve ilaçların çocukların ulaşabileceği şekilde saklanmaması gerektiği düşünülmüştür. İntoksikasyon olgularının büyük kısmının, zehirlenme olguları açısından adli tıbbi kriterler çerçevesinde belirlenen yaşamsal tehlike ölçütlerini karşılamadığg, sadece 9'unda (\%3.9) yaşamsal tehlike oluştuğu, 6'sında (\%2.6) oluşan sağlık zararının basit tıbbi müdahale ile giderilebilecek derecede hafif olmadığı, geri kalanlarında ise $(\% 97.5)$ basit tıbbi müdahale ile giderilebilecek derecede hafif olduğu belirlenmiştir. Yaşamsal tehlike oluşan 9 olgunun tamamı karbonmonoksite maruz kalan olgulardır (Tablo 7).

Çocuk intihar girişimleri: Adli rapor düzenlenen çocuk olguların 32'sinde (\%2.9) intihar girişimi öyküsü mevcut olup bunların büyük çoğunluğu $(n=25)$ ilaç/madde alımı şeklindedir. Çocuk acil servise zehirlenme nedeniyle başvuran olguların değerlendirildiği çalışmalarda, orijini özkıyım olan zehirlenme oranı, bizim çalışmamıza göre oldukça yüksek olup bir çalışmada \%12, diğerinde \%22 bildirilmiştir $(28,29)$. Bu sonuç, çocuk acil servise yansıyan her olgunun adli tıp polikliniğine yansımamış olmasından kaynaklanabilir.

Cinsel istismar olgular1: Toplam 93 cinsel istismar olgusunun yaklaşık dörtte üçü kadındır. Olguların 20'sinde, iç beden muayenesinde cinsel istismarı düşündüren bulgu saptanmamıştır. 61 olguda, muayene ve adli görüşme sonucu ulaşılan bulgular ya da soruşturma evraklarının incelenmesi ile ulaşılan bilgiler neticesinde, cinsel istismar düşünüldüğü belirtilmiştir. $\mathrm{Bu}$ durum, fizik muayeneye ek olarak, yeterli bir öykü alma, ruhsal değerlendirme, adli ve tıbbi evrakın incelenmesinin önemi açısından literatürle uyumlu bulunmuştur $(11,30)$. Diğer yandan, cinsel istismar olgularında, bulguların elde edilmesi ve raporlanması açısından olay sonrası erken dönemde başvuru yapılması önemlidir (31).

Adli psikiyatrik olgular: $\mathrm{Bu}$ olguların çoğunluğunda (\%83.5), Türk Ceza Kanunu kapsamında, küçüğün işlediği fiilin hukuki anlam ve sonuçlarını algılayıp algılamadığı veya davranışlarını yönlendirme yeteneğinin yeterince gelişip gelişmediğinin sorulmuş olması ve bu olguların çoğunluğunun erkek olması da literatürle uyumludur (32-37). Bu durum, erkeklerin kadınlara göre, aile gözetiminden daha uzak olması, ev dış1 yaşantılarının genellikle daha fazla olması ve suça daha meyilli yapıda olması ile açıklanabilir. Evlilik için uygun olup olmadiğ tamamının kadın olması da, benzer çalışmalarla uyumlu bulunmuştur (36). Evliliğe uygun olup olmadığı sorulan kadınların eş adayları genellikle 18 yaşından daha büyük olduğundan bu sorun, bir kadın sorunu olarak karşımıza çıkmaktadır.

Sonuç olarak, okul öncesi dönem başta olmak üzere, küçük yaştaki çocukların kaza nedenli zehirlenmelere karşı gözetim altında bulundurmaları, evlerde gereksiz ilaç 
bulundurulmamas1, ilaçların çocukların erişemeyeceği yerlere konulması, yaralanmalı trafik kazalarının azaltılması için alınacak kurumsal önlemler yanı sıra toplumsal olarak farkındalık çalışmaları yapılması, özellikle ergenlerin ateşli silah ve kesici-delici aletlerden uzak durmaları, iletişim ve kişilerarası şiddeti önlemeye yönelik programlar yapılması, suça sürüklenen çocukların topluma kazandırılabilmesi için diğer tüm çocuklardan daha fazla ve farklı bir eğitime tabi tutulması, toplumsal cinsiyet eşitliği ve cinsel dokunulmazlık konularında hem çocuklar hem yetişkinlere farkındalık eğitimleri yapılması gerekmektedir. Dezavantajlı çocuklara rapor düzenleme sorumluluğu olan adli tıp çalışanları ile çocukların korunması konusunda sorumluluğu olan

\section{Kaynaklar}

1. Çinar O, Acar YA, Cevik E, ve ark. Acil Servise Başvuran 0-18 Yaş Grubu Adli Olguların Özellikleri. Anatol J Clin Investig. 2010;4(3):148-51.

2. Büken E, Yaşar ZF. Başkent Üniversitesi Ankara Hastanesi Acil Servisine başvuran çocuk adli olguların değerlendirilmesi. Adli Tıp Bült. 2015;20(2):93-8.

3. Turla A, Aydın B. Ondokuz Mayıs Üniversitesi Tıp Fakültesi'ne başvuran adli nitelikteki çocuk olguların değerlendirilmesi. Adli Tıp Bült. 2007;12(3):106-11.

4. Sever M, Saz EU, Koşargelir M. Bir üçüncü basamak hastane acil servisine başvuran adli nitelikli çocuk hastaların değerlendirilmesi. Ulus Travma Acil Cerrahi Derg. 2010;16(3):260-7.

5. Aksu H, Demirkaya SK, Özgür BG, Gün B. Aydın ilinde bir yıldaki çocuk ve ergen adli olguların değerlendirilmesi. Anadolu Psikiyatri Derg. 2013;14:369-77.

6. Türkmen N, Akgöz S, Çoltu A, Ergin N. Uludağ Üniversitesi Tıp Fakültesi Acil Servisine başvuran adli olguların değerlendirilmesi. Uludağ Üni Tıp Fak Derg. 2005;31(1):25-9.

7. Tıraşçı Y, Durmaz U, Altınal A, ve ark. Dicle Üniversitesi Adli Tip Anabilim Dalınca 2012-2015 yılları arasında düzenlenen adli raporların retrospektif olarak değerlendirilmesi. Dicle Tıp Derg. 2016;43(3):424-30.

8. Uluçay $\mathrm{T}$, Ziver A, Zeyfeoğlu Y, ve ark. Celal Bayar Üniversitesi Tıp Fakültesi Adli Tıp Polikliniğine başvuran olguların değerlendirilmesi. Adli Tıp Derg. 2006;20(2):22-9.

9. Ketenci HÇ, Kır MZ, Başbulut AZ, ve ark. Erzurum Adli Tıp Şube Müdürlüğü'ne müracaat eden olguların değerlendirilmesi. Adli Tıp Derg. 2013;27(2):87-93.

10. Demir ÖF, Aydın K, Turan F, Yurtseven A, Erbil B, Gülalp B. Analysis of pediatric forensic cases presented to emergency department. Turk Arch Ped. 2013;48(3):235-40.

11. Kara B, Biçer Ü, Gökalp A. Çocuk istismarı. Çocuk Hast Sağlığı Derg. 2004;47(2):140-51.

12. Herrmann B, Navratil F. Sexual abuse in prepubertal children and adolescents. Endocr Dev. 2012;22:112-37.

13. Güngörer V, Yildırım NK. Evaluation of intoxicated patients hospitalized in a newly-opened level two pediatric intensive care unit. Turk Pediatri Ars. 2016;51:35-9.

14. Ünlü $\mathrm{G}$, Aksoy $\mathrm{Z}$, Ersan EE. İntihar girişiminde bulunan çocuk ve ergenlerin değerlendirilmesi. Pam Med J. 2014;7(3):176-83.

15. Even KM, Armsby CC, Bateman ST. Poisonings requiring admission to the pediatric intensive care unit: a 5-year review. Clinical Toxicol. 2014;52(5):519-24.

16. Demirci S, Doğan KH, Erkol Z, Deniz İ. Konya'da cinsel istismar yönünden muayenesi yapılan çocuk olguların değerlendirilmesi. Türkiye Klinikleri $\mathrm{J}$ Foren Med. 2008;5(2):43-9. birimlerin işbirliği ve etkileşim içinde olması yararlı olacaktır.

Çocukların sağlıklı bir şekilde yetişmesi için tüm olumsuz faktörlerin belirlenmesi ve önleme çalışmalarının yapılması adına adli muayeneler de çocukları koruma girişimleri açısından önemli firsatlar olabilir (35). Çocukların sağlıklı yetişebilmesi, adli olaylar, travma ve şiddet olaylarına karışmalarının en aza indirilebilmesinde aile, eğitim kurumları ve hükümetlere önemli görevler düşmektedir.

Etik Kurul Onayı: Bu çalışma için, Muğla Sıtkı Koçman Üniversitesi Bilimsel Araștırmalar ve Yayın Etiği Kurulu'nun 26.07.2019 tarih ve 119 karar numaralı onayı alınmıştır.

17. Barutçu N, Yavuz MF, Çetin G. Cinsel saldırı sonrası mağdurun karșılaștığı sorunlar. Adli Tıp Bülteni. 1999;4(2):41-53

18. Asirdizer M, Sunay YM, Emre A, Gürol C. Infant and adolescent deaths due to home accidents in İstanbul. Turkish J Pediatrics. 2005;47(2):141-9.

19. Güven FMK, Bütün C, Beyaztaș FY, Eren SH, Korkmaz İ. Cumhuriyet Üniversitesi Tıp Fakültesi Hastanesi'ne başvuran adli olguların değerlendirilmesi. ADÜ Tıp Fak Derg. 2009;10(3):23-8

20. Karanfil R, Zeren C. Kahramanmaraş Sütçü İmam Üniversitesi Tıp Fakültesi Adli Tıp Anabilim Dalına 2009. 2010 yıllarında başvuran olguların retrospektif olarak değerlendirilmesi. Adli Tıp Derg. 2011;25(2):183-90.

21. Yavuz FM, Basturk P, Yavuz SM, Yorulmaz C. Cerrahpaşa Tıp Fakültesi Acil Servisi'ne başvuran adli olguların değerlendirilmesi. Adli Bilimler Derg. 2002;1(2):21-6.

22. Duramaz BB, Yıldırım HM, Kıhtır HS, Yeşilbaş O, Sevketoğlu E. Evaluation of forensic cases admitted to pediatric intensive care unit. Turk Pediatri Ars. 2015;50(3):145-50.

23. Serinken $M$, Özen $M$. Characteristics of injuries due to traffic accidents in the pediatric age group. Ulusal Travma Acil Cerrahi Derg. 2011;17(3):243-7.

24. Tambay G, Satar S, Kozaci N, ve ark. Retrospective analysis of pediatric trauma cases admitted to the emergency medicine department. JAEM. 2013;12(1):8-12.

25. Altun G, Azmak D, Yilmaz A, Yilmaz G. Trakya Üniversitesi Tıp Fakültesi Acil Servisi'ne başvuran adli olguların özellikleri. Adli Tıp Bülteni. 1997;2(2):62-6.

26. Korkmaz T, Erkol Z, Kahramansoy N. Acil servise gelen pediatrik adli olguların değerlendirilmesi: retrospektif bir çalışma. Medical Bulletin Haseki. 2014;52:271-7.

27. Bozlu G, Kuyucu N. Cocuk acil servise son beş y1lda gelen zehirlenmeler: 1734 olgunun değerlendirilmesi. Adli Tip Bülteni. 2018;23(2):106-9.

28. Demirgan EB, Erol M, Demirgan S, Yiğit Ö, Türkay M. Çocuk acil polikliniğine başvuran ilaç ile zehirlenme olgularının retrospektif değerlendirilmesi. Okmeydanı Tıp Derg. 2014;30(3):128-134

29. Yorulmaz A, Akbulut H, Yahya İ, Aktaş R, Emiroğlu HH, Peru H. Cocuk acil servisine zehirlenme nedeni ile başvuran olguların geriye dönük olarak değerlendirilmesi. J Pediatr Emerg Intensive Care Med. 2017;4:96-103.

30. Gümüş AE. Çocuk cinsel istismarı şüphesinin bildirimi öncesinde çocukla yapılacak ilk görüşme. Klinik Psikiyatri. 2017;20(1):45-58.

31. Özdemir B, Celbis O. Cinsel saldırıya uğramış çocukta erken ve geç muayene bulgularının değerlendirilmesi. Medicine Science. 2012;1(1):55-64.

32. Bilgin NG, Avcı A, Çekin N, Savran B. Farik-i mümeyyizlik muayenesi için gönderilen çocukların biyopsikososyal özellikleri. Adli Tıp Bülteni. 2001;6(3):103-10. 
33. Kurtulus A, Salman N, Günbet G, Boz B, Cenger CD, Acar K. Denizli İli'nde 12-15 yaş arasındaki suça sürüklenen çocukların sosyodemografik özellikleri. Pam Med J. 2009;2(1):8-14.

34. Cantürk G. Çocuk suçluluğunda adli psikiyatrik değerlendirme. STED. 2005;14(2):31-4.

35. Dokudan EY, Uzunyayla Z, Bilgi S, Ünüvar GÜ. Juvenile Delinquency and Medico-Legal Perspective for Promoting Children's Health. Eastern J Medical Science. 2019;4(1):16

36. Ayaz M, Ayaz AB, Soylu N. Cocuk ve ergen adli olgularda ruhsal değerlendirme. Klinik Psikiyatri. 2012;15(1):33-40

37. Göker Z, Hesapçıŏlu ST, Sarp KS, Kandil ST. KTÜ Tıp Fakültesi Çocuk-Ergen Ruh Sağlığı ve Hastalıkları Polikliniğine, son iki yılda başvuran adli olguların değerlendirilmesi. Adli Tıp Derg. 2006;20(3):1-5.28. Lipton RB, Hamelsky SW, Kolodner KB, Steiner TJ, Stewart WF. Migraine, quality of life, and depression: a population-based case- control study. Neurology. 2000;55(15):629-35.

29. Kucukgoncu S, Tek C, Bestepe E, Musket C, Guloksuz S. Clinical features of night eating syndrome among depressed patients. Eur Eat Disord Rev. 2014; 22(2):102-8.
30. Breslau N, Davis GC, Andreski P. Migraine, psychiatric disorders, and suicide attempts: an epidemiologic study of young adults. Psychiatry Res. 1991;37(1):11-23.

31. Ligthart L, Nyholt DR, Penninx BW, Boomsma DI. Headache shared genetics of migraine and anxious depression. Headache. 2010;50(10):1549-60.

32. Breslau N, Andreski P. Migraine, personality, and psychiatric comorbidity. Headache. 1995;35(7):382-6.

33. Frediani F, Villani V. Migraine and depression. Neurol Sci. 2007;28(2): 161-5

34. Young WB, Peres MFP, Rozen TD. Modular headache theory. Cephalalgia. 2001;21(8):842-9.

35. Cady R, Schreiber C, Farmer K, Sheftellet F. Primary headaches: a convergent hypothesis. Headache. 2002;42(2): 204-16.

36. Lipton RB. Tracing transformation: chronic migraine classification, progression, and epidemiology. Neurology 2009;72(5):3-7.

37. Winter A, Berger K, Buring E, Kurth T. Body mass index, migraine, migraine frequency and migraine features in women. Cephalalgia. 2008;29(2):269-78 